\title{
TRADE NAME INFRINGEMENT AS UNFAIR COMPETITION
}

"Unfair competition" is the name, perhaps unfortunate, that has been given to the doctrine that one should not be allowed to sell his goods as those of another. ${ }^{1}$ Although there is a broader concept of the doctrine, this discussion will be restricted to a consideration of unfair competition in the "palming off" or "passing off" situation. " The "palming off" of goods or services is usually accomplished by adopting a trade-mark or trade name ${ }^{3}$ identical or very similar ${ }^{4}$ to one already in use. Because the law of trademarks is closely related to the law of unfair competition, frequently being referred to as "but a part of the broader law of 'unfair competition," "s some comment regarding the former is necessary to explain the latter.

\section{TRADE-MARK PROTECTION}

The law of trade-marks is purely statutory. ${ }^{6}$ The owner of a valid registered trade-mark or name has the exclusive right to its use, ${ }^{7}$ but for effective registration the mark must have been used as a trade-mark prior to its registration, and the holder must have been the first to adopt the mark. ${ }^{8}$ Registration itself gives no exclusive right in the mark, ${ }^{\circ}$ but is prima facie evidence of the ownership of the mark. ${ }^{10}$

Statutory trade-mark protection, however, does not extend to all words or names. A word common to the language that describes the origin, char-

1 See Lane Bryant, Inc. v. Maternity Lane, 173 F.2d 559, 563 (9th Cir. 1949); Barnes v. Cahill, 56 Cal. App. 2d 780, 783, 133 P.2d 433, 435 (1943).

2 One authority is highly critical of the "palming-off" definition and refers to it as "... merely the designation of a typical class of cases of unfair competition." 1 CAILMANA, UNFarR CoMrPETtTION AND TRADE MARRS 61 (1945). Nor is there any reference to the "palming-off" situation in the code section which defines unfair competition as "unfair or fraudulent business practice." CAL. CIv. CoDE \$3369(3). The real strength of the law of unfair competition lies in its fexibility and its adaptability to more and more situations not encompassed in the "palmingoff" category. See, generally, Chafee, Unfair Competition, 53 HARv. L. REv. 1289 (1940).

$3 \mathrm{~A}$ trade-mark is generally applicable to the commodity, whereas a trade name, technically, designates the particular busimess, but the same fundamental principles of law and equity apply. DEFUNIAK, HANDBOOR OF MODERN EQUTTY 108-109 (1950). The writer will use the terms in the broad, interchangeable sense and not in the technical sense nor as defined in the Restatements of Torts.

4 "Similarity, not identity, is the usual recourse when one party seeks to benefit himself by the good name of another." Jackman v. Mau, 78 Cal. App. 2d 234, 239, 177 P.2d 599, 602 (1947) (Quoting Celluloid Mfg. Co. v. Cellunite Mfg. Co., 32 Fed. 94, 97 (C.C.D.N.J. 1887)). 5 Stork Restaurant v. Sahati, 166 F.2d 348, 354 (9th Cir. 1948).

- Brooks Bros. v. Brooks Clothing of Calif., 60 F. Supp. 442, 447 (S.D. Cal. 1945).

7 Cat. Bus. \& Prof. Code $\$ 14202 ; 60$ Stat. 430 (1946), 15 U.S.C. \& 1057 (Supp. 1951); Amdur, Trade-Mark Law and Practice 257-258 (Lanham Act ed. 1948).

8 Cax. Bus. \& Prof. Code $\$ \S 14245,14270,14400 ; 60$ Stat. 427 (1946), 15 U.S.C. $\S 1051$ (Supp. 1951).

9 Hopkins, The Law of Trademarks, Tradenames and Unfatr Competimion \& 31 (4th ed. 1924). In fact, registration may be cancelled upon a showing of prior use by another. CAL. Bus. \& Prof. Code § 14247; 60 StaT. 433 (1946), 15 U.S.C. § 1064 (Supp. 1951):

${ }^{10}$ Car. Bus. \& Prof. Code $\$ 14271$; 60 Stat. 430 (1946), 15 U.S.C. $\$ 1057$ (b) (1946); Derenberg, Trade-Mark Protection and Unfatr Trading 16, 24 (1936). 
acter, or quality of the article or service cannot be a valid statutory ${ }^{10 a}$ trade-mark, nor can a personal name, ${ }^{11}$ with an exception in federal law to be considered later. ${ }^{112}$ Such words and names are a part of the public domain and are not subject to the exclusive appropriation of anyone.

Though not protected by statute, descriptive words and personal names are in common use as trade names, and the equities are just as strong for protecting them against the efforts of others to "cash in" on the name as in cases where statutory protection is afforded. The law of unfair competition developed to meet this need, and in its early development, merely supplemented the law of statutory trade-marks by protecting names used in trade or business that had acquired a "secondary meaning." 1a

\section{PROTECTION FROM UNFAIR COMPETITION}

The law of unfair competition is of judicial creation. ${ }^{13}$ It may be regarded as the common law of trade-mark protection. A word or name is said to have a "secondary meaning" when it has been used so long and so exclusively by one firm or proprietor that the public has come to associate the name with the person using it. ${ }^{14}$ The word no longer has merely a dictionary meaning. It now also designates the source of the goods or services; that is, in its "secondary meaning" it refers to the party using it as a trade name. However, while the technical trade name owner has the exclusive right to the use of his trade name, the "owner" of a secondary meaning trade name has only limited right in his name. He has the exclusive right to its use only in its new meaning; ${ }^{15}$ the public can continue to use it in its "primary" meaning, as a common word, and may even use it as a trade name if the second use is so foreign to the first that there is no possibility of confusion or damage to the first user. ${ }^{16}$ In its "secondary meaning," within the area of possible confusion, its owner is entitled to the same degree of protection that the technical trade name owner enjoys. ${ }^{17}$

There is no particular length of time that an appropriator must use the

10a Writers frequently refer to a validly registered trade-mark or trade name as a "technical" trade-mark or "technical" trade name. In this discussion the term "statutory" has bcen substituted for "technical" in order to emphasize the fact that such marks and names derive their protection from statute.

11 Cal. BUs. \& Prof. Code \$ 14242; 60 Stat. 428 (1946), 15 U.S.C. \& 1052(e) (1946). "A trade-mark may not consist of a designation or part of a designation that relates only to any of the following: (a) The name of the thing marked. (b) The quality of the thing marked. (c) The description of the thing marked. (d) The place where the thing is produced." CAx. BUs. \& Prof. CODE \$14201. Prior to 1941 this section was substantially enbodied in CaL. CIV. Code $\S 991$.

11 a See text at note 28 infra.

121 CaltuaranN, op. cit. supra note 2 at 58.

13 Brooks Bros. v. Brooks Clothing of Calif., supra note 6 at 447.

14 See Academy of Motion Pictures v. Benson, 15 Cal. 2d 685, 689, 104 P.2d 650, 652 (1940); 150 A.L.R. 1067 (1944); 2 CartaranN, op. cit. supra note 2, at 1008.

152 CALIMAANN, op. cit. supra note 2, at 1010; AMrDUR, op. cit. supra note 7, at 260.

16 One may even "borrow" a statutory trade-mark or name if the new use is so foreign as to prevent confusion. See Derenberg, op. cit. supra note $10, \S \S 34,35$ for a consideration of the limitations on trade-mark rights.

17 See Eastern Columbia v. Waldman, 30 Cal. 2d 268, 271, 181 P.2d 865, 867 (1947). 
name in order to establish secondary meaning, ${ }^{18}$ nor need his use be absolutely exclusive, or even first within the field of possible confusion. The period of use is, naturally, an important factor that the court should consider in determining the existence of secondary meaning, but modern advertising methods make possible the acquisition of secondary meanimg in a matter of weeks.

In Del Monte Special Food Co. v. California Packing Corp. ${ }^{19}$ the plaintiff was neither the first nor the only user of the name in the food industry, but was by far the predominant user. When the defendant commenced the marketing of a food product under the same name, the public believed the plaintiff was the source of the product. The defendant's contention that the plaintiff was not entitled to relief because third parties had employed the same name in the same field was rejected by the court and an injunction was granted. The decision seems correct. The public associated the plaintiff with the name despite the use by third parties, and the defendant's acts were no less unfair or deceptive by reason of the plaintiff's inability to show exclusive and first use.

The increasingly liberal attitude of the California courts is indicated by a recent decision of the Califorma Supreme Court upholding the trial court's finding that the title of an unsuccessful play had acquired secondary meaning. ${ }^{20}$ The play had closed more than two years before the defendant's use of the title as a motion picture title. The play had a total run of only three weeks, during which time it was modestly advertised in Philadelphia and New York City newspapers. Some 20,000 "heralds" were distributed and 50 posters were displayed. The play was mentioned three times in Los Angeles newspapers, and appeared in the "Shows in Rehearsal" section of Variety, a theatrical magazine. Judging from the reviews the play received, the meager total audience of 3,750 persons was probably anxious to forget the play and its title.

The writer's objection to the decision is the court's definition of the term "public" for purposes of secondary meaning. "Public" is generally interpreted in secondary meaning cases as designating a "substantial part of the trade" or a substantial portion of that segment of the public purchasing the product or service. ${ }^{21}$ In this decision the public is said to be "... not very many of the people of a place, but so many of them as contradistinguishes then from a few." ${ }^{22}$ The court adopted the definition of "public" used in a stock offermg case. The writer questions the advisability

183 Restaterenen, TORTs $\$ 716$, comment $b$ (1938); Axmur, op. cit. supra note 7, at 272274. "... [S]econdary meaning is a question of fact, and the all important fact is the trade meaning of the mark regardless of the length of use." 1 NIMS, UNFAIR COMPETIIION AND TRADE MARKs 163 (4th ed. 1947).

1034 F.2d 774 (9th Cir. 1929).

20 Jackson v. Universal Pictures, 36 Cal. 2d 116, 222 P.2d 433 (1950).

21 AxDUR, op. cit. supra note 7, at 274-275. "Universality of recognition, therefore, is not required. What is required is that a substantial section of the purchasing public should be proved to identify the trade name with the plaintiff's goods ...." I NIMs, op. cit. supra note 18, at 161, quoting Cutier, Passing OFf 48.

22 Jackson v. Universal Pictures, supra note 20 at 122, 222 P.2d at 437. 
of the adoption of this definition. It would seem better to use the term "public" as it has been developed in the secondary meaning field.

Some courts grant relief in general terms of unfair competition without expressly referring to the doctrine of secondary meaning, while other decisions emphasize the secondary meaning aspect of the particular case. Nevertheless, the theory of the plaintiff's attack is the same in all cases. Any difference in emphasis is of no iniportance, despite the California Supreme Court's remarks in the Modesto Creamery ${ }^{23}$ decision. In that case the court stated that the trial court's finding of secondary neaning was not necessary to grant relief because "[a]II that is enjoined is the use of such name in a manner calculated to deceive purchasers into mistaking defendant's product for that of plaintiff." 24

The court's rejection of the need for a finding of secondary meaning was actually a rejection of the basis of the action. There cannot be deception unless the public, intending to deal with the first user, night deal with the second user by mistake. The mistake occurs because the name inducing the purchase or dealing is associated by the public with the first user. The public's association gives the name its secondary meaning. ${ }^{25}$ The Modesto Creamery court's remarks are illogical. Secondary meaning is the foundation of an unfair competition action. ${ }^{26}$ While there are a few decisions elsewhere in accord with the Modesto Creamery approach, ${ }^{27}$ no subsequent California decision has attempted to differentiate between secondary meaning and unfair competition, perhaps because of a fuller development and understanding of the concept of secondary meaning.

It is interesting to note that the federal law of trade-nuarks has been extended to permit the registration of trade names that have acquired a secondary meaning. ${ }^{28}$ If a "secondary meaning" trade name is registered, any action on it should be brought as a trade-mark infringement suit rather than as an unfair conpetition suit. ${ }^{29}$ Such registration would not seem to enlarge the owner's right to the use of the word; the public may continue to use the word in its primary meaning unless confusion results. ${ }^{30}$

23 Modesto Creamery v. Stanislaus Creamery Co., 168 Cal. 289, 142 Pac. 845 (1914).

24 Id. at 284,142 Pac. at 847.

25 Noms, op. cit. supra note $18, \S 37$.

26 The doctrine of secondary meaning has been, in fact, described as ". . the genesis of the law of unfair competition." Academy of Motion Pictures v. Benson, supra note 14 at 689, 104 P.2d at 652 .

$2 \pi$ Gillette Safety Razor Co. v. Triangle Mechanical Laboratories Corp., 4 F. Supp. 319 (E.D.N.X. 1933); Edward G. Budd Mfg. Co. v. Wilson Body Co., 7 F.2d 746 (E.D. Mich. 1925); 150 A.L.R. 1077 n.51 (1944).

2860 STAT. 428 (1946), 15 U.S.C. $\$ 1052$ (f) (1946) ; AMDUR, op. cit. supra note 7, at 242253, 296-302.

29 AxrDUR, op. cit. sutpra note 7, at 258 n.8. The procedural advantages of registration are mentioned in the text at note 10 supra and note 43 infra.

30 See Armstrong Co. v. Nu-Enamel Corp., 305 U.S. 315, 335-336 (1938) ; American Dis. tilling Co. v. Bellows \& Co., 102 Cal. App. 2d 8, 15-17, 226 P.2d 751, 756 (1951); DERENBERG, . op. cit. supra note 10, at 334; 2 CALLAaAN, op. cit. supra note 2, at 1400. 


\section{Nature of the Unfair Competition Action}

California courts have said that the unfair competition action is based equally on the rights of the public and of the plaintiff. ${ }^{31}$ Such dicta, however, indicate the motive rather than the basis of the action and shed no light on the question of who can bring the action or when it can be brought. It would be more advantageous to consider the nature of plaintiff's right in the use of his trade name.

There are dicta in numerous early California cases to the effect that no proprietary interest in the trade name is necessary for relief. ${ }^{32}$ It is true that the common law trade name "owner" has no exclusive right to the name itself and cannot control the use of his name to the extent the statutory trade name owner can, but he nevertheless would seem to have an interest in the nature of a property right..$^{33}$ After all, it is the goodwill that is being protected in both the unfair competition suit and the statutory trade-mark mfringement suit, ${ }^{34}$ and goodwill is property, ${ }^{35}$ whether represented by a secondary meaning trade name or a statutory trade name. The recognition of the plaintiff's interest as a property right adds to an appreciation of what elements are essential to an unfair competition action.

\section{Elements No Longer Essential to the Action}

The requirenents for injunctive relief differ in certain respects from the requirenients for damages ${ }^{36}$ but as damages usually are not an issue in appellate cases, this discussion will primarily concern itself with the prerequisites for injunctive relief. Before considering the elements necessary to secure relief, it would be wise, for purposes of clarity, to point out what is not necessary for an unfair competition action in California.

First, actual inarket competition between the litigants is not necessary ${ }^{37}$

31 Sec, e.g., Academy of Motion Pictures v. Benson, supra note 14 at 691, 104 P.2d at 653; Jackman v. Mau, supra note 4 at 238, 177 P.2d at 602 .

32 See, e.g., Modesto Creamery v. Stanislaus Creamery, supra note 23 at 293, 142 Pac. at 846; Dodge Stationery Co. v. Dodge, 145 Cal. 380, 78 Pac. 879 (1904).

33 See Eastern Columbia v. Waldman, stipra note 17 at 269-270, 181 P.2d at 866; Jackman v. Mau, supra note 4 at 238 , 177 P.2d at 602. DEF UNIAK, op. cit. supra note 3 , at 110-111. See Johnson v. Twentieth Century-Fox Film Corp., 82 Cal. App. 2d 796, 187 P.2d 474 (1947), for a good discussion of the nature of one's rights in a secondary meaning name and its transferability in the literary field.

34 See Brooks Bros. v. Brooks Clothing of Calif., supra note 6 at 447-448; 1 Nmas, op. cit. supra note 18 , at 85 .

35 CaL. Crv. Code $\$ 655 ; 1$ Calmarann, op. cit. supra note 2 , at 20,$22 ; 1$ Nars, op. cit. supra note 18 , at 78 .

30 "A clear distinction is advanced in all the cases, both English and American, between the right to an injunction and the right to damages and profits." 2 Calriman, op. cit. supra note 2, at 1461 .

37 Stork Restaurant v. Sahati, supra note 5 ; Del Monte Special Food Co. v. California Packing Corp., supra note 19; Academy of Motion Pictures v. Benson, supra note 14; Winfield v. Charles, $77 \mathrm{Cal}$. App. 2d 64, 175 P.2d 69 (1946). "For if there is any principle established firmly in the law of the Ninth Circuit, and in the law of California, which must govern the unfair competition phase of the case, ... it is that infringement and unfair competition may be found to exist as between non-competitive fields and products." Sunbeam Corp. v. Sunbeam Lighting Co., 83 F. Supp. 429, 430 (S.D. Cal. 1949). "Emphasis should be placed on the word 'unfair', rather than 'competition'." Wood v. Peffer, 55 Cal. App. 2d 116, 122, 130 P.2d 220, 224 (1942). Contra: Scutt v. Bassett, 86 Cal. App. 2d 373, 194 P.2d 781 (1948). 
because it is the goodwill and reputation of the plaintiff that is being protected, and goodwill and reputation can be damaged as readily by a noncompetitor cashing in on the name, as by one who is actually diverting trade from the plaintiff to himself. ${ }^{38}$ However, confusion or deception may be less likely where the products or services are noncompetitive. ${ }^{30}$ The very name of the doctrime is a misnomer. The Restatement of Torts has avoided the use of the term altogether by dealing with the doctrine under the topic Confusion of Source. .0 $^{40}$

Nor is proof of fraudulent intent necessary for injunctive relief. ${ }^{41}$ The definition of unfair competition in the Civil Code uses the words "unfair" and "fraudulent" in the disjunctive. ${ }^{42}$ In those jurisdictions where fraud is still required, this prerequisite is one of the distinguishing features of the unfair competition action, because in the statutory trade-mark infringement suit fraud is presumed from the infringement. ${ }^{13}$ Even where fraud is said to still be an element of the action, it has come to mean nothing more than "a conscious use of a confusingly similar mark." 44 The defendant's continuance of the infringement after he has knowledge of the plaintiff's rights would be "tantamount to fraud."

38 ePlaintiff has established a reputation for reliability and meritorious products. If articles which are not produced by him are attributed to him or associated with his name, the injury is obvious." The injury results from ". . . a representation to the public that it produces a product which it does not in fact produce and over which it has no control." Winfield v. Charles, supra note 37 at 70,175 P.2d at 74.

30 "Where inarket competition is absent, it is a corollary that the likelihood of confusion in the mind of the buyer decreases." Sunbeam Furniture Corp. v. Sunbeam Corp., 191 F.2d 141, 145 (9th Cir. 1951). In Alhambra Transfer Co. v. Muse, 41 Cal. App. 2d 92, 106 P.2d 63 (1940), the court considered deception impossible because the litigants were engaged in the real estate and transfer and storage businesses, respectively.

403 Restatencent, ToRTs 534 (1938).

41 Stork Restaurant v. Sahati, supra note 5 ; Wood v. Peffer, supra note 37 ; see, e.g., McCord Co. v. Plotnick, 108 Cal. App. 2d 392, 395, 239 P.2d 32, 34 (1951); Weatherford v. Eytchison, 90 Cal. App. 2d 379, 384, 202 P.2d 1040, 1043 (1949); Hoover Co. v. Groger, 12 Cal. App. 2d 417, 419, 55 P.2d 529, 530 (1936); Derenberg, op. cit. supra note 10, \& 66; 2 CaLIMANN, op. cit. supra note $2, \$ 86.1$ (a). See, also, note 42 infra.

42 See Wood v. Peffer, supra note 37 at 124, 130 P.2d at 225. "In an action for injunctive relief against unfair competition it is unnecessary to prove that defendant's conduct was fraudulent since Civil Code, Section 3369, declares that unfair competition shall 'include unfair or fraudulent business practice." "McCord v. Plotnick, sicpra note 41 at 395,239 P.2d at 34 . In Dunston v. Los Angeles Van Co., 165 Cal. 89, 131 Pac. 115 (1913), the court defined "unfair trade dealing" (unfair competition) in terms of fraud, and went on to say that mere similarity did not establish fraud, and that, because relief rests on protection from defendant's fraud, the fraud must be proved. However, in 1933, after American Automobile Ass'n v. American Automobile Owners Ass'n, 216 Cal. 125, 13 P.2d 707 (1932), which quoted the Dunston decision with approval, the California legislature enacted Civil Code $\$ 3369(3)$ which defined unfair competition differently. Fraud has definitely not been essential to the action since 1933, whatever the law may have been in California prior to that date. Since 1933 there have been two appellate decisions which have repeated the Dunston concept of unfair competition. No reference was made to the 1933 legislation. These two cases are not really in conflict with the writer's position. In the more recent case, Alhambra Transfer Co. v. Muse, supra note 39, the court based its decision on the impossibility of deception, the litigants being active in completely unrelated fields. In the other case, Pohl v. Anderson, 13 Cal. App. 2d 241, 56 P.2d 992 (1936), the court found that the public had not been umisled or deceived by the defendant's acts.

43 AMDUR, Op. cit. stepra note 7, at 263-265.

44 CaLLManN, op. cit. supra note 2 , at 1400-1401.

45 See Stork Restaurant v. Sahati, supra note 5 at 360 ; Brooks Bros. v. Brooks Clothing of Calif., supra note 6 at $455-456$. 
ages in addition to an injunction, actual fraud must be proved in Califor$\mathrm{nia}^{46}$ and most other jurisdictions, ${ }^{47}$ because the defendant might be quite innocent as to his past infringement. It is primarily in respect to the fraud element that the requirements for a damage suit differ froin those for an injunction. $^{48}$

\section{Elements Essential to the Action}

What is necessary for injunctive relief in an unfair competition action is that the name that is sought to be protected has acquired a secondary meaning, and that the defendant has unfairly used the name to the plaintiff's injury. ${ }^{49}$ The injury need not have occurred in fact; all that is necessary is a showing of threatened, imminent harm..$^{50}$

The secondary meaning element means nothing more than that the name designates the plaintiff in the eyes of the public, and that the defendant's use of the same or similar name would be likely to result in confusion. ${ }^{51}$ Actual confusion need not be proved. ${ }^{52}$ All that is necesary is that a purchaser of ordinary intelligence could reasonably be confused. ${ }^{53}$

\section{Extent of Protection}

The extent of protection equity affords in a particular case may depend on whether the word is fanciful, descriptive, or is a surname. The greatest protection is offered to words that are fanciful, ${ }^{54}$ that is, words that are ar-

46 Modesto Creamery v. Stanislaus Creamery Co., supra note 23; Wood v. Peffer, supra note 37 .

472 CallaranN, op. cit. supra note $2, \S 89.2$ (a)(b). For a long list of cases, see 2 CaIIMLANN, op. cit. susra note 2 , at 1516 n.62.

48 Another distinction between the two actions, for example, is that laches is often a defense to a damage action but is usually not a defense to an injunction action. 2 CAIIMANN, op. cit. supra note $2, \S 87.3$ (c).

40 See McGraw-Hill Pub. Co. v. American Aviation Associates, 117 F.2d 293, 296 (Cir. D.C. 1940).

60 "It is sufficient if injury to the plaintiff's business is threatened or imminent to authorize the court to intervene to prevent its occurrence." Winfield v. Charles, supra note 37 at 70, 175 P.2d 73, quoting from Schwarz v. Schwarz, 93 Cal. App. 252, 255, 269 Pac. 755, 756 (1928).

51 To determine whether there is unfair competition "[t]be universal test question is whether the public is likely to be deceived." Pohl v. Anderson, supra note 42 at 242,56 P.2d at 992. "It is the tendency to mislead and not the actual result which is the test." Palmer v. Gulf Pub. Co., 79 F. Supp. 731, 738 (S.D. Cal. 1948).

52 See Cal. Prune Ass'n v. Nicholson Co., 69 Cal. App. 2d 207, 219, 158 P.2d 764, 770 (1945). But in Pohl v. Anderson, supra note 42, and in Ida May Co. v. Ida May Ensign, 20 Cal. App. 2d 339, 66 P.2d 727 (1937), relief was denied because there were findings that the public was not deceived, rather than that the public was not likely to be deceived. It would seem that the plaintiff need not prove deceit to secure injunctive relief, but that relief will be denied if the defendant can prove no deceit.

53 American Distilling Co. v. Bellows \& Co., supra note 30; 2 Catmarann, op. cit. supra note $2, \S 81.2$. The law "... safeguards from deception also the ignorant, the inexperienced, and the gullible." Stork Restaurant v. Sahati, supra note 5 at 359 . But the law does not protect the careless or indifferent purchaser. American Automobile Ass'n v. American Automobile Owners Ass'n, supra note 42 at 138, 13 P.2d at 713. In determining the likelihood of deception the court will tabe cognizance of a limited or specialized clientele. Palmer v. Guif Pub Co., supra note 51 (petroleum industry techmical publications).

v4 See Stork Restaurant v. Sahati, supra note 5 at 355 ; Palmer v. Gulf Publishing Co., supra note 51 at 734 . 
bitrarily selected as trade names and are completely nondescriptive. A newcomer has no excuse or justification whatever for adopting a confusingly similar name in such situations. ${ }^{55}$

Trade names composed entirely of descriptive words may also acquire secondary meaning, ${ }^{56}$ but narrower protection is given here than where fanciful names are used because the excuse exists that the defendant is truthfully describing his goods. The defendant may even argue that he is using the words in their primary sense only, and that he cannot be enjoined. Such an argument may have been persuasive prior to the maturity of the secondary meaning doctrine, but would be ineffective today. The court would simply apply the association test: "... what does the mark as used by plaintiff represent or mean to the public, and what in contrast, does the mark used by the defendant represent?" $5 \tau$

The protection a court will grant is probably least adequate where the trade name is also a family name. The policy affording protection clashes with the concept that every man has the right to use his own name in his business even though such use may be detrimental to others using the same name. The courts have, not too successfully, attempted to reconcile these principles.

\section{USE OF FAMILY NAMES}

The problem of the use of the same or similar family names may be subdivided into two parts. First, whether protection will be given at all when confusion is likely, and second, whether the protection, if given, is adequate.

An older statement of the rule regarding the use of family names is to be found in the frequently quoted Tomsky decision: ${ }^{58}$

Every man has the absolute right to use his own name in his own business, even though he may interfere with and injure the business of another bearing the same name, provided he does not resort to any artifice or do any act calculated to mislead the public as to the identity of the establishments or to produce injury to the other beyond that which results from sinilarity of names .... It is not the use of a man's own name that is condernned; it is the dishonesty practiced in the use of it.

Applying the rule literally as stated, and giving weight to its qualification, whatever injury results from the mere similarity of names is dammum

55 In Stork Restaurant v. Sahati, supra note 5 at 361 , the court pointed out that when a nondescriptive name is sought, the defendant had an infinite choice of other names from which to select.

56 Goodyear Rubber Co. v. Fotre, 95 F. Supp. 48 (S.D. Cal. 1951) ("Gold Seal") ; Academy of Motion Pictures v. Benson, supra note 14 ("The Academy," "The Motion Picture Academy"). Compare Brown v. Hook, 79 Cal. App. 2d 781, 180 P.2d 982 (1947) ("Machinists' Union No. 68") with American Automobile Ass'n v. American Automobile Owners Ass'n, supra note 42 ("American Automobile," "AAA"). See Palmer v. Gulf Pub. Co., supra note 51, regarding the difficulties presented by descriptive word names in the magazine field.

57 Brown v. Hook, sılpra note 56 at 799, 180 P.2d at 993, quoting NoMs, UNFAIR CompeTITION AND TRADE MaRks 962 (3d ed. 1929).

5s Tomsky v. Clark, 73 Cal. App. 412, 418, 238 Pac. 950, 952 (1925). 
absque injuria. " . . . [A] charge of infringement or unfair competition cannot be predicated upon the bona fide and innocent use by an individual of his own name in his own business, even though such use may incidentally interfere with or injure the business of another person or organization of the same or a similar name." "59 The defendant's use of his name must be dishonest to be enjoinable.

This view would offer the fortuitous individual with the same name as one that has acquired a secondary meaning the opportunity to pirate the prior user's goodwill with impunity if he is clever enough not to overdo the infringement. The rationalization is that the prior user should have known of this danger when he decided to use his family name to designate his business, and he cannot now be heard to complain. ${ }^{60}$ The result is that honest businessmen find their goodwill diluted and stolen, and the public is deceived and thereby injured, but man's "sacred right" to use his own name is preserved in all its glory. ${ }^{61}$

Fortunately, the Tomsky statement of the rule has not been followed literally in California. A more enlightened view has won favor with the courts of California and elsewhere. As Nims puts it, "[i]t is doubtful if, as we now conceive of the duty of man to his fellows, one has any greater right to inflict unnecessary injury and hardship on his neighbor by use of his own nanie than he has to do so by use of a common word of the langnage." ${ }^{62}$ How can a person claim to be making an innocent and bona fide use of his name when he knows that the public will thereby be confused and deceived? The argument that the defendant's use would be tantamount to fraud applies with equal force where the trade name involved is a family name as where it is a common word. It would seem more just to protect the public and the first users than to protect newcomers when confusion would result from the new use of the name.

Callmann contends that the "sacred right" theory is fallacious. The only sacred right involved is man's inalienable right to use his name to identify and symbolize his individual personality. The courts have misapplied this right in trade name cases. When one engages in business under one's surname, the name is being used to symbolize the business and not the personality, unless the business is highly personal. The name becomes a trade name and should be treated as any other trade name. Likewise, the newcomer is not exercising any sacred right when he uses the name as a trade name, and is deserving of no special consideration. ${ }^{\text {e3 }}$

59 American Distilling Co. v. Bellows \& Co., supra note 30 at 18, 226 P.2d at 75. The statement should not be regarded as a serious expression of the court's attitude because it was a quotation inserted to illustrate the court's contention that the law also offers protection from the unfair use of similar names.

60 "The first user, in choosing a family name for his business, assumes the risk of others of the same name using such name fairly in their own business." Horlick's Malted Milk Corp. v. Horkick, 50 F. Supp. 417,419 (E.D. Wis. 1943).

61 For the most recent ballyhoo regarding this "sacred right" see Ida May Co. v. Ida May Ensign, supra note 52 at 344,66 P.2d at 729.

$621 \mathrm{Nars}$, op. cit. supra note 18, at 195 .

632 Carticani, op. cit. supra note $2, \$ 85.2$ (d) (1). 
If the Callmann analysis is rejected, it may be argued that the liberal view protecting the goodwill a surname represents actually adds substance to the concept that everyone has the right to do business under one's own name. One could enter any field where the name would not cause confusion and could develop his name as a trade name without the fear of losing his goodwill by the intrusion of other merchants of the same or similar names into the same field. A policy protecting the first user's secondary meaning surname would tend to encourage the fair use of surnames in business while discouraging the abuse of the privilege of using one's name in business. On the contrary, under the Tomsky view, the right or privilege would be one that legitimate merchants could not afford use, because the goodwill and reputation one develops can be dissipated by all comers having the same or similar names.

The basic conflict between these two approaches becomes most apparent when the amount of protection to be given is an issue.

\section{"Explanatory Phrase" or Absolute Injunction}

The protection granted usually takes one of two forms. The defendant may be permitted to use his name if it is accompanied by an "explanatory phrase," or he may be absolutely enjoined from using his name in any man. ner in the particular business if confusion as to the source of the article or service is likely to occur.

The "explanatory phrase" rule was developed by the "sacred right" adherents to compromise the conflicting interests involved in family name cases. ${ }^{64}$ The rule permits a person to use his name in any business he desires to conduct, even though the same or similar name may have acquired secondary meaning. Where confusion is likely, the newcomer is required to use the name accompamied by an "explanatory phrase" to the effect that he is not related in any way to the existing busmess or establishment of that same name. ${ }^{65}$ The theory is that the rule guarantees the full measure of "sacred right" to everyone, and yet protects the public and the prior users by removing the possibility of deception. Unfortunately, the protection the prior users receive is frequently very inadequate. ${ }^{66}$ Often, all that is required by way of explanation is that the infringer add his given name or his initials to the surname. ${ }^{67}$ " "Confusion is created by the very explanation

64 The compromise is not very satisfactory. This is not a problem capable of a "have-yourcake-and-eat-it-too" solution.

652 CallmanN, op. cit. supra note $2, \S 85.2$ (c); Derenberg, op. cit. supra note $10, \S 33$.

${ }^{60}$ Callmann, Derenbrerg, and Nimis all consider the "explanatory phrase" rule inadequate. Derenberg, $o p$. cit. supra note $10, \S 33 ; 2$ CallimanN, op. cit. supra note $2, \$ \S 85.2$ (c), 85.2(d) 2; 1 Nmas, op. cit. supra note 18, \$\$ 70, 71. The "Baker's Chocolate," "Waterman Pen," and "Rogers Silverware" cases are cited as examples of the inadequate protection the limited injunction provides. On one occasion the infringer himself became the victim of another parasite. 1 Nmas, op. cit. supra note 18, at 202.

67 'It has, for example, been held sufficiently distinguishing if a word describing a line of business, the first name, a second family name, initials, or even a suffix, were added to the famous name, or even if the defendant merely avoided a plural or possessive form of the name." 2 Carimann, op. cit. supra note 2 at 1380-1381. In Horlick's Malted Milk Corp. v. Horluck's, 59 F.2d 13 (9th Cir. 1932), the court merely enjoined the use of the defendant's confusingly similar name in the plural or possessive form. 
intended to avert confusion." "6s The plaintiff may have to come into court repeatedly because the defendant has evaded the spirit of court order while literally complying with it. If this remedy is used, a completely adequate "explanatory phrase" should be required the first time a defendant is brought into court. Anything less is an invitation to evasion.

In many cases confusion and deception can be prevented only by an absolute injunction prohibiting any use whatever of the name in the business the defendant is then conducting. One fairly recent Califorma appellate decision, Hoyt Heater Co. v. Hoyt, ${ }^{69}$ went all the way and granted an absolute injunction against the defendant's use of his family name in any form in his business. The defendant Hoyt was operating a water heater repair business and had listed his name among the authorized Hoyt Heater Co. agencies in the telephone book classified ads. The court realized that an "explanatory phrase" would have been totally inadequate.

There is dictum in the Hoyt case to the effect that where the newcomer "... cannot use his own name without inevitably representing his goods as those of another he may be enjoined from using his name in connection with his business."70 Would a Califorma court actually go as far as this dictum indicates and grant an absolute injunction whenever confusion is inevitable? The Hoyt court did not have to decide that point because it relied heavily on the trial court's finding of calculated deceit in order to distinguish the case from several unfavorable earlier decisions, such as, the Ida May, ${ }^{11}$ Dunston, ${ }^{72}$ and American Automobile Ass' $n^{73}$ cases in which no relief whatever was granted. These cases could, however, be distinguished on other grounds. For example, in the American Automobile Ass'n case the court found that the public was not likely to be misled or deceived by the defendant's acts. The Ida May decision was based on the finding that the public had not been misled or deceived, ${ }^{74}$ and the Dunston case was rendered obsolete by the enactment of Civil Code Section 3369(3). ${ }^{75}$ The Hoyt finding of calculated deceit was not necessary to distinguish those cases, and such a finding should not be required to support an absolute injunction.

The prevailing view in the United States requires that the defendant must have committed some act or resorted to some "artifice ... . calculated to deceive" in order to permit the issuance of an absolute injunction. ${ }^{76}$ The presence of actual fraud is no doubt added justification for an absolute injunction, but it is questionable if it should be essential. Such a finding is not necessary to grant absolute injunctions where the trade name is composed of common words. Whether an absolute injunction should issue should de-

\footnotetext{
68 Derenaerg, op. cit. supra note 10 , at 370 .

6068 Cal. App. 2d 523, 157 P.2d 657 (1945). Noted in 59 HARv. L. Rev. 140 (1945).

70 Hoyt Heater Co. v. Hoyt, supra note 69, at 527, 157 P.2d at 659 (1945).

71 Ida May Co. v. Ida May Ensign, supra note 52.

72 Dunston v. Los Angeles Van Co., supra note 42.

13 American Automobile Ass'n v. American Automobile Owners Ass'n, supra note 42.

74 See note 52 supra regarding this finding.

75 See note 42 supra.

T6 2 Callarann, op. cit. supra note $2, \S 85.2$ (b) (1).
} 
pend solely on whether it is reasonably necessary for effective relief in the particular case. ${ }^{\pi 7}$ The formula is simple, and logically should be applied to all cases: If any use of the word or name by the defendant would involve a violation of the plaintiff's rights, it should be enjoined absolutely and unconditionally. If the infringement and deception arises out of the misuse of the word rather than out of the use itself, a limited injunction is proper. ${ }^{78}$

In a 1947 decision, shortly after the Hoyt case, the California Supreme Court expressed itself strongly in favor of giving practical relief in the form of absolute injunctions wherever necessary, and while that case involved a common word trade name and not a family name, ${ }^{70}$ the same vigorous policy is advisable where family names are involved. Absolute injunctions have the virtues of: (1) giving effective protection where an "explanatory phrase" limited injunction will not; (2) making evasion of the spirit of the law by infringers much more difficult; (3) relieving the first users of the burden of repeated appearances in court against the same infringers; (4) having a generally healthy influence on the business world by discouraging would-be infringers from embarking on piracy campaigns. ${ }^{80}$ Absolute injunctions in this field are not entirely destructive of the "sacred right" to do business under one's own name. The right may still be enjoyed in any field or trade where confusion will not occur. ${ }^{81}$

\section{The Tarantino Case}

The inost recent decision involving the use of a surname as a trade name in California is the case of MacSweeney Enterprises v. Tarantino. ${ }^{82}$ In that case the plaintiff corporation was operating a restaurant on Fisherman's Wharf in San Francisco' under the name "Tarantino's." "83 Large sums were spent in advertising, and the restaurant acquired an international reputation. The defendant corporation, owned and operated by members of the Tarantmo family, who were joined as defendants, began marketing a cocktail sauce under the name "Tarantino's." The defendants had never before used the name on any of their fish and allied products. The name was printed on the defendants' labels in script almost identical to that customarily employed by the restaurant. Although five Tarantinos were active in the defendant company, the singular possessive form of the word was used,

77 In Dodge Stationery Co. v. Dodge, supra note 32, an absolute injunction was denied because it was not considered necessary to properly protect the plaintiff's rights. "Each case must necessarily stand upon its own facts." Id. at 392,78 Pac. at 884 . Cf. Hoyt Heater Co. v. Hoyt, supra note 69 . The difference in the method of advertising in the cases was such that it was apparent that an "explanatory phrase" would be imadequate in the Hoyt case.

78 Id. at 1501-1502.

T0 Eastern Columbia v. Waldman, supra note 17.

80 History reveals the results of a pohicy of granting inadequate protection. "... [A] large number of Bakers discover that they are called by God to to go into the chocolate business, and several Watermans find that their peculiar talents can best be realized in the manufacture of fountain pens." Chafee, supra note 2, at 1296.

81 See 1 Nars, op. cit. supra note 18, at 221 , for an argument in favor of this position.

82106 Cal. App. 2d 504, 235 P.2d 266 (1951).

83 Plaintiff acquired the right to use the name "Tarantino's" by contract from two people of that name who were originally associated with the restaurant. 
in the same way as by the restaurant. The trial court found that the defendants' acts were "deliberate and calculated to deceive the public into believing that the plaintiff was the preparer" of the sauce, and that the acts injured the plaintiff's "standing, reputation and good-will." 84 The defendants were enjoined from using the name "Tarantino's" or a similar name in connection with the marketing of the cocktail sauce. This decision was upheld, although the plaintiff did not market any cocktail sauce of its own and the name involved was the family name of the individual defendants.

The injunction in the Tarantino case did not prohibit all use of the name in defendants' business; it did prohibit any use of the name on the sauce labels. The court apparently realized that an "explanatory phrase" would have been inadequate to prevent deception in that fact situation. The writer cannot accept the suggestion that the injunction could have been narrower and yet still protect the plaintiff. ${ }^{85}$ If anything, the injunction might justifiably have been broader and include those of the defendants' other products the public would be likely to associate with the plaintiff. ${ }^{86}$

The Tarantino decision repeats with favor the dicta in the Hoyt and $J a c k m a n^{87}$ decisions to the effect that an absolute injunction is proper in surname cases. ${ }^{88}$ A significant point in the Tarantino decision was the court's recognition that "... there is an important distinction between the use of a family name as a firn name, and the use of such name in the trademark sense." 89 This distinction offers a cautious court a "middle road" to follow and yet grant adequate relief in cases involving the marketing of an article, by enjoining absolutely the use of the name as a trade name in connection with the product, but permitting the defendant to include his name in the fornal title of the firm. ${ }^{30}$ There is danger of evasion and deception even in this situation, however, since the infringer can make the firm name the predominant feature of his label. In such cases the court inight well enjoin the use of the surname in the firm title itself. ${ }^{21}$

The distinction is of no value, and should not be applied, where service industries are involved, as in the Hoyt case, and the firm name designates the business for advertising purposes. In this and similar situations where

84 MacSweeney Enterprises v. Tarantino, supra note 82 at 509, 235 P.2d at 269.

85 Note, 13 OHro S. L. J. 303 (1952). The belief was expressed that the plaintiff would have been adequately protected had the defendants been required to either change the script of the lettering or place the name "Tarantino's" in a subordinate position on the labels. Such an injunction would probably have led to additional litigation and possibly the destruction of the plaintiff's goodwill.

$86 \mathrm{~A}$ broader injunction would have removed any temptation the defendants might have to use the name on their other products.

87 Jackman v. Mau, supra note 4 at 238, 177 P.2d at 602 (Defendant's given and family names combined to resemble plaintiff's surname).

$88 \mathrm{Mac}$ Sweeney Enterprises v. Tarantino, supra note 82 at 511,235 P.2d at 270.

80 Id.

20 For example, in Sunbeam Furniture Corp. v. Sunbeam Corp., supra note 39, the court enjoined the defendant's use of the word "Sunbeam" on its products but permitted the word's use in the firm name because confusion of source would not thereby result.

OI If the defendant resorted to such a subterfuge, would it not be an act "calculated to deceive" and satisfy even the conservative view's prerequisites for an absolute injunction? 
deceit is likely to result from the use of the surname in the firm name, an absolute injunction against any use of the surname in the particular business is the only effective solution. If such is the case, the court need not hesitate to grant the injunction.

R. Reaves Elledge, Jr.* 